\title{
MAQASHID AL-SYARI'AH: Kajian Mashlahah Pendidikan dalam Konteks UN Sustainable Development Goals
}

\author{
Mohamad Anang Firdaus \\ IAIN Kediri, Indonesia \\ anangfirdausm@gmail.com
}

\begin{abstract}
This paper will discuss the concept of maqashid Sharia as an Islamic education approach in realizing global goals. Education as a development instrument for Human Resources (HR) that encourages competent management and use of Natural Resources (SDA) should play an important role in the realization of the Sustainable Development Goals (SDGs) program. And educational goals oriented to the SDGs program can be conceptualized by the maqashid shari'ah approach. Because Ibn 'Asyûr thinks that the benefits that will be achieved by maintaining the maqashid shari'ah are the main objectives of Islamic sharia. In the context of social piety, noble character is the ultimate goal of Islamic education. This is part of the Islamic mission as a religion which is "rahmatan lil 'alamin". By spreading the Mashlahah in all the joints of life. On a global scale, Islamic education is required to be able to answer various contemporary problems that arise and create benefits for all parties. It can be seen from the purpose of Islamic shari'ah. Substantially the objectives of the Shari'a which we call "Maqashid alSyari'ah" contain benefits. And SDGs also contain the mashlahah that the world wants to achieve. Although this study is included in the shari'ah discipline, according to alNahlawi, the concept of maslaha has a close relationship with education. In this case, Islamic education must be able to realize the Sustainable Development Goals (SDGs) agreed upon by 193 world leaders on September 25, 2015 and then through the UNDP (United Nations Development Program).
\end{abstract}

Keyword: Education, Mashlahah, Maqashid Syari'ah, SDGs

Makalah ini akan membahas konsep maqashid syariah sebagai pendekatan pendidikan Islam dalam mewujudkan tujuan global. Pendidikan sebagai instrumen pembangunan Sumber Daya Manusia (SDM) yang mendorong untuk cakap dalam mengelola dan memanfaatkan Sumber Daya Alam (SDA) harusnya bisa memainkan peranan penting dalam upaya realisasi program Sustainable Development Goals (SDGs). Tujuan pendidikan yang berorientasi pada program SDGs bisa dikonsepsi dengan pendekatan maqashid syari'ah. Karena Ibn 'Asyûr beranggapan kemaslahatan yang akan diraih dengan memelihara maqashid syari'ah merupakan tujuan utama syariah Islam. Dalam konteks kesalehan sosial, budi pekerti yang luhur menjadi tujuan akhir pendidikan Islam. Hal ini menjadi bagian misi Islam sebagai agama yang "rahmatan lil 'alamin". Dengan menyebarkan mashlahah dalam semua sendi kehidupan. Dalam skala global, pendidikan Islam dituntut untuk dapat menjawab berbagai masalah kontemporer yang muncul dan menciptakan kemaslahatan untuk semua pihak. Hal itu bisa dilihat dari tujuan syari'at Islam. Secara substansial tujuan syariat yang kita sebut dengan "Maqashid al-Syari'ah" mengandung kemashlahatan. SDGs juga memuat mashlahah yang hendak dicapai dunia. Meski kajian ini masuk dalam disiplin ilmu syari'ah, 
namun menurut al-Nahlawi, konsep mashlahah ini memiliki hubungan yang erat dengan pendidikan. Dalam hal ini, pendidikan Islam harus mampu mewujudkan Tujuan Pembangunan Berkelanjutan (SDGs) yang telah disepakati oleh 193 pemimpin dunia pada 25 September 2015 dan kemudian melalui UNDP (United Nations Development Programme).

Kata Kunci : Pendidikan, Mashlahah, Maqashid Syari'ah, SDGs

\section{A. Pendahuluan}

Dalam fungsinya, pendidikan hendaknya mampu mengantarkan umat manusia menuju kemaslahatan, yang berujung pada kebahagiaan dunia dan akhirat. Pendidikan juga harusnya bisa menjadi sarana dalam mengembangkan serta melestarikan nilai-nilai kebajikan yang universal dan norma-norma Islam kepada generasi penerus bangsa. Secara substansial maqashid al-syari'ah mengandung kemashlahatan, baik ditinjau dari maqashid al-syari' (tujuan Tuhan) maupun maqashid al-mukallaf (tujuan mukallaf). ${ }^{130}$ Meski kajian ini masuk dalam disiplin ilmu syari'ah, namun menurut Abdurrahman al-Nahlawi, konsep mashlahah ${ }^{131}$ ini memiliki hubungan yang erat dengan pendidikan. Oleh karena itu konsep mashlahah harus menjadi tujuan yang harus dicapai dan

130 Begitu pula dari sudut maqasid al-mukallaf, maqasid al-syariah mengandung empat aspek pula, yaitu: (1) Pembicaraan mashlahah, pengertian, tingkatan, karakteristik, dan relativitas atau keabsolutannya. (2) Pembahasan dimensi linguistik dari problem taklif yang diabaikan oleh juris lain. Suatu perintah yang merupakan taklif harus bisa dipahami oleh semua subjeknya, tidak saja dalam kata-kata dan kalimat tetapi juga dalam pengertian pemahaman linguistik dan kultural. Al-Syathibi mendiskusikan problem ini dengan cara menjelaskan dalalah asliyah (pengertian esensial) dan ummumiyah (bisa dipahami orang awam). (3) Analisa pengertian taklifdalam hubungannya dengan kemampuan, kesulitan dan lain-lain. (4) Penjelasan aspek huzuz dalam hubungannya dengan hawa dan ta'abud.

جلب المصالح ودفع Secara umum, tujuan yang hendak dicapai dari ajaran syariah Islam adalah (menghasilkan kemaslahatan dan mencegah kerusakan). Secara bahasa, kata "mashlahah" memiliki makna yang sama dengan kata "manfaat". Dalam bahasa Arab, kata مصلحة adalah masdar dari kata صلح yang artinya '(membuat) kebaikan.' Seperti kata منفعة yang merupakan masdar dari kata نفع yang artinya '(memberi) kemanfaatan.' Menurut al-Ghazalī, mashlahah adalah usaha yang berorientasi pada pemeliharaan maksud-maksud syariah, yang mencakup pemeliharaan agama (hifz al-Din), kehidupan (hifz al-Nafs), nasab (hifz al-Nasl), akal (hifz al-Aql), dan harta (hifz al-Mal), baik pada level darūriyyah, hajjīyyah maupun tahsiniyyah. Kelima eksistensi tersebut disebut sebagai al-Usūl al-Khamsah. Karena itu, semua perbuatan yang ditujukan untuk memelihara al-Usūl al-Khamsah dinamakan sebagai maslahat dan semua perbuatan yang menyebabkan rusaknya, bahkan hilangnya eksistensi al-Usūl al-Khamsah disebut sebagai mafsadah. Sehingga mencegah terjadinya mafsadah berarti melakukan mashlahah, karena perbuatan tersebut dapat menghasilkan mashlahah. Lihat: Abu Hamid al-Gazalì, AlMushtașfa min 'Ilm al-Ushûl, Juz II, (Kairo: Dar al-Hadits, 2011), hlm. 286-287 
diwujudkan. ${ }^{132}$ Dalam pandangan Ibn 'Asyûr, mashlahah didefinisikan sebagai suatu sifat yang melekat pada perbuatan yang mengakibatkan terciptanya kebaikan atau kemanfaatan, baik secara kolektif maupun individu. ${ }^{133}$ Menurutnya tujuan utama syariah Islam adalah untuk mewujudkan keteraturan alam dan memelihara kehidupan dari kerusakan, dan itu artinya syariah Islam diturunkan untuk mewujudkan mashlahah dan menjauhkan mafsadah. Karena itu keseluruhan dari hukum syar'i selalu berorientasi pada tercapainya mashlahah dan hilangnya mafsadah (baik mashlahah dan mafsadah yang dimaksud tampak maupun tersembuyi). ${ }^{134}$ Selanjutnya Ibn 'Asyûr membagi maslahat menjadi tiga kategori; Pertama, berdasarkan tingkat kepentingannya untuk umat, maslahat dibagi menjadi mashlahah darūrīyah, hajjīyah, dan tahsinìyah. Kedua, berdasarkan konteks cakupannya mashlahah dibagi menjadi dua, mashlahah kullīyah dan juz'ìyah. Ketiga, berdasarkan tingkat kepastiannya mashlahah dibagi menjadi mashlahah qat'īyah, dannīyah, dan wahmīyah. ${ }^{135}$

Berkenaan dengan paradigma mashlahah, Zabidi berpendapat bahwa dalam perdebatan atas wacana mashlahah terdapat dua arus pemikiran yang membentuk dua tipologi paradigma, yaitu paradigma litreral dan liberal. Munculnya kedua paradigma ini dipicu oleh persoalan apakah kemaslahatan (mashlahah) sebagai basis konstruksi fiqh kontekstual harus tunduk kepada teks ataukah teks itu yang harus "patuh" kepada mashlahah. Paradigma literal mengedepankan pola pikir keberagaman ortodoks, sehingga ia dengan segala upaya berusaha menaklukkan realitas (mashlahah) di bawah otoritas teks. Sedangkan paradigma liberal justru menjadikan realitas (mashlahah) sebagai acuan yang mesti dicermati dalam menyikapi sebuah peristiwa hukum. ${ }^{136}$

132 Abdurrahman al-Nahlawi, Ushûl al-Tarbiyah al-Islâmiyah, (Beirut: Dar al-Fikr, 2003), hlm. 69-74.

133 Țahir Ibn 'Asyûr, Maqâsid al-Syari'ah al-Islâmiyah, (Amman: Dar al-Nafais, 2001), hlm. 65.

134 Ibid, hlm. 75-78.

135 Ibid, hlm. 78.

136 Ahmad Zayyaduz Zabidi, "Paradigma Utilitarianistik dalam Istimbat Hukum Islam", dalam Jurnal al-Ihkam, Vol. 07, No. 2, Desember 2012, hlm. 378. 
Dua arus pemikiran yang dimaksud oleh Zabidi adalah pemikiran alJuwayni dan al-Ghazali yang memperkenalkan paradigma literal. Serta pemikiran 'Izz al-Din bin 'Abd al-Salam dan al-Thufi yang menjadi tonggak pemikiran dalam paradigma liberal.137 Menurut al-Juwayni, kemaslahatan selalu ditundukkan di bawah hegemoni teks. Begitu pula al-Ghazali yang menegaskan bahwa tolok ukur kemaslahatan tidak dapat dikembalikan kepada penilaian manusia karena sangat rentan dengan dorongan nafsu insaniyah. Karenanya, tolok ukur kemaslahatan haruslah bermuara kepada kehendak atau tujuan syarî́ah yang telah digariskan di dalam teks-teks suci. ${ }^{138}$ Sedangkan paradigma liberal diperkenalkan oleh 'Izz al-Din bin 'Abd al-Salam, yang mengatakan bahwa keliru jika nalar tidak dijadikan piranti guna menentukan kemaslahatan. Untuk itu ia menilai bahwa konklusi-konklusi rasio dari beberapa obyek penelitian, adat kebiasaan, dan asumsi-asumsi yang dianggap valid, memiliki peran besar guna 'memilah' dan 'memilih' kemaslahatan dan kerusakan duniawi. Walaupun demikian, ia tidak menafikan bahwa kemaslahatan dan kerusakan ukhrawî hanya dapat diketahui melalui suara wahyu (divine revelation). ${ }^{139}$

Dalam konteks perkembangan zaman, dunia internasional semakin dasar akan upaya mewujudkan keteraturan alam dan memelihara kehidupan dunia dari kerusakan. Artinya misi tersebut selaras dengan tujuan syariah Islam dengan mashlahahnya. Ketika agama Islam mempunyai platform bahwa ia adalah agama yang membawa rahmat untuk semesta, dan selaras dengan perkembangan zaman dan tempat, maka harusnya pendidikan Islam mampu mengakomodir kemaslahatan yang telah dirumuskan oleh dunia global. Sehingga pendidikan Islam mampu berkontrinbusi atas terwujudnya cita-cita global yang telah dirumuskan bersama-sama oleh mayoritas negara di tingkat internasional. Dengan upaya ini, Islam akan dikenal sebagai agama yang

137 Zabidi, "Paradigma Utilitarianistik...., hlm. 378-380.

138 Al-Ghazali, al-Musthasfâ ..., hlm. 286.

139 'Izz al-Din bin Zaghifah, al-Maqashid al-'Âmmah li al-Syari'at al-Islamiyah, (Kairo: Dar alShafwah li al-Thaba'ah wa al-Nasyr wa al-Tawzi', 1996), hlm. 107. 
berkemajuan dan mempunyai perhatian terhadap kemaslahatan dunia dalam skala yang lebih luas.

\section{B. Mashlahah dan SDGs}

Dalam sejarah pemikiran Islam, mashlahah atau kemaslahatan menjadi masalah penting untuk dikaji dan direalisasikan. Semua urusan yang mengitari ajaran Islam berputar pada poros kemaslahatan. Pembahasan tentang masalah ini bisa dilihat dalam kajian tujuan-tujuan syariat (maqashid al-syari'ah) yang sudah dibahas sejak era klasik para ulama seperti Ibrahim al-Nakha'i, Hujjah al-Islam al-Ghazali al-Thusi, 'Izzuddin Ibn Abd al-Salam, Syaikh al-Islam Ibn Taimiyah, dan Abu Ishaq al-Syathibi di dalam karya-karya mereka. Di era modern, kajian maqashid al-syari'ah juga dibahas oleh oleh sejumlah ulama seperti Syekh Tahir Ibn 'Asyûr, Abd al-Wahhab Khalaf, Syekh Muhammad Sa'id Ramadhan al-Buthy, Syekh 'Alal Al-Fasi, Jasser Auda dan ulama lainnya. ${ }^{140}$

Dalam menentukan mashlahah, Tariq Ramadan telah menawarkan sebuah cara penetapan sesuatu sebagai mashlahah, meskipun dalam prosesnya terhitung rumit dan membutuhkan perenungan yang mendalam. Penetapan mashlahah menurut Tariq Ramadan ditempuh dengan tiga kriteria yang harus yang harus diperhatikan, yaitu: (1) haqiqiyyah, bersifat otentik dan definitif, bukan spekulatif (wahmiyyah); (2) kulliyyah, bersifat umum, dalam artian tidak hanya mengakomodir kepentingan seseorang atau sekelompok orang tertentu. (3) Tidak bertentangan dengan teks yang bersifat qath'i. ${ }^{141}$ Di sisi yang lain, mashlahah juga bisa ditemukan dengan menggunakan sebuah pendekatan ilmu ushul al-figh yang dikenal dengan istilah al-mashlahah al-mursalah. Dikatakan mursalah (yang terlepas) karena teknik ini menentukan mashlahah yang telah ditentukan tidak disinggung oleh teks al-Qur'an dan hadits (silent source of law).

\footnotetext{
140 Muhammad Lutfi Hakim, "Pergeseran Paradigma Maqāsid Al-Syari'ah: Dari Klasik Sampai Kontemporer," dalam Jurnal Al-Manahij, Vol. X No. 1, 2016, hlm. 10-11.

${ }_{141}$ Tariq Ramadan, Radical Reform: Islamic Ethics and Liberation, (Oxford: Oxford University Press, 2008), hlm. 41.
} 
Teknik ini dipakai oleh sejumlah ulama karena mayoritas teks al-Qur'an dan hadits tidak bersifat definitif (qath'i), maka ruang gerak al-mashlahah al-mursalah menjadi sangat leluasa. Dan inilah yang menurut Ramadan menjadi makna ijtihad itu sendiri. ${ }^{142}$

Al-Thufi bahkan lebih bebas dan memberikan keleluasaan lebih dalam menentukan mashlahah. Menurutnya mendahulukan mashlahah atas teks merupakan suatu keharusan yang ia dukung dengan empat landasan di dalam menelaah dan meletakkan dasar-dasar teori mashlalah, yaitu: Pertama, kemerdekaan berfikir perlu ditegakkan dalam upaya menemukan mashlahah maupun mafsadah. Akal sehat manusia mempunyai kemampuan untuk menentukan mana yang mashlahah dan mana yang mafsadah. Kedua, mashlahah merupakan dalil syar'i yang independen. Artinya, validitas kehujjahan mashlahah tidak bergantung pada teks. Sebaliknya, keberadaan mashlahah dapat ditunjukkan dengan pembuktian empiris melalui hukum-hukum kebiasaan.

Ketiga, obyek penggunaan teori mashlahah adalah hukum-hukum mu'amalah dan hukum-hukum kebiasaan ('adah). Karenanya, kajian mashlahah tidak dapat menjamah sakralitas ritus keagamaan (ibadah mahdlah), karena yang dapat menghubungkan ibadah dengan ajaran suci hanyalah teks dan ijma', bukan mashlahah. Keempat, mashlahah merupakan dalil syar'i yang terpenting, sehingga eksistensinya harus berada di atas teks dan ijma'. Prioritas mashlahah di atas teks dan ijma' bukan bermaksud menafikan teks maupun ijma', tetapi sebaliknya mashlahah ummat diproyeksikan untuk menetralisir keumuman teks dan ijma'. Bisa juga, menjadikan mashlahah sebagai pengejawentahan penafsiran dan penjelas akhir atas teks dan ijma' yang memiliki indikasi hukum mujmal (global), sebagaimana fungai hadis ketika berhadapan dengan teks alQur’an yang mujmal. ${ }^{143}$

142 Ibid, hlm. 66.

143 Mushthafa Zayd, al-Mashlahah fî Tasyri' al-Islami, (Beirut: Maktabah Wahdah, t.t.), hlm. 233-235. 
SDGs tersebut ditetapkan oleh PBB pada 25 September 2015 di New York dengan masa berlaku mulai Januari 2016 hingga Desember 2030.144 SDGs ini merupakan kelanjutan dari MDGs (Millennium Development Goals) yang telah berakhir pada $2015 .{ }^{145}$ Lantas pertanyaan yang muncul sekarang, apakah SDGs telah memenuhi tiga prasyarat milik Ramadan, sehingga ia bisa dikatakan sebagai sebuah mashlahah dalam konteks dunia internasional?. Jika 17 point the global goal dipahami secara mendalam, dengan tanpa mengabaikan kondisi global yang sedang melanda dunia internasional, maka menurut teori Ramadan dengan tiga prasyaratnya, the global goal bisa dikatagorikan sebagai sebuah mashlahah dalam cakupan global. Apa lagi jika kita menilai SDGs dengan menggunakan teori al-Thufi, maka akan sangat mudah menyimpulkan bahwa SDGs adalah sebuah mashlahah dalam dunia global.

\section{SDGs Sebagai Standar Maqashid dalam Konteks Global}

M. Hashim Kamali menegaskan bahwa dalam menyelesaikan masalah kontemporer, kembali pada makna harfiah teks adalah sesuatu yang tidak mungkin menyelesaikan masalah (problem solving), bahkan bisa menjadi masalah tersendiri (part of problem), yakni teralienasinya ajaran Islam dalam dinamika kehidupan. Satu-satunya solusi yang tepat adalah menangkap prinsip-prinsip dasar, makna-makna universal, dan tujuan-tujuan yang terkandung di dalamnya untuk kemudian diterapkan dalam wajah baru yang sesuai dengan semangat merealisasikan kemaslahatan umum. Inilah yang dinamakan dengan maqashid based ijtihad. 146

\footnotetext{
144 www.satu-indonesia.com, diakses pada 14 Juli 2018.

145 Dalam ranah global, ada 17 point tujuan yang ditetapkan oleh PBB dan telah disepakati oleh 193 negara anggota PBB yang berkomitmen untuk mewujudkannya. Karena ke-17 tujuan tersebut dinilai mengandung mashlahah dan kebaikan yang urgent dan sangat dibutuhkan dalam menghadapi perkembangan dunia pada beberapa dekade ke depan. 17 tujuan tersebut dikenal dengan nama Sustainable Development Goals (Tujuan Pembangunan Berkelanjutan) yang disingkat dengan "SDGs". Dengan kata lain, "SDGs" adalah sebuah mashlahah secara common sense, karena ia merupakan hasil persepsi orang kebanyakan (the man in the street). Karena ke-17 tujuan (the global goal) tesebut merupakan real objek dan aktual yang dijumpai oleh semua orang.

${ }_{146}$ M. Arfan Muammar, Studi Islam: Perspektif Insider/Outsider, (Jogjakarta: IRCiSoD, 2013), hlm. 387.
} 
Ijtihad berbasis maqashid bersifat luwes-dinamis, karena dapat menampung berbagai perkembangan terkini, asalkan mampu mengantarkan pada kemaslahatan alam semesta (rahmatan li al-alamin). Atas dasar itu, Jasser Auda menyarankan agar menjadikan United Nations Development Program (UNDP) sebagai standar ilmiah dalam menentukan realisasi maqashid syariah masa kini. Hal ini dikarenakan UNDP tersebut disusun berdasarkan lebih dari 200 indikator, termasuk mengukur partisipasi politik, kemampuan baca-tulis (literasi), keikut sertaan dalam pendidikan, harapan hidup, akses mendapatkan air bersih, ketenagakerjaan, standar hidup dan kesetaraan gender. ${ }^{147}$

Sustainable Development Goals (SDGs) merupakan hasil kesepakatan 193 pemimpin dunia pada 25 September 2015, tentang 17 Sasaran Global (The Global Goals) yang diharapkan dapat tercapai pada tahun 2030, yaitu148:

1. Tanpa kemiskinan (no poverty): hilangkan kemiskinan dalam bentuk apa pun di seluruh penjuru dunia;

2. Tanpa kelaparan (zero hunger): hilangkan kelaparan, mencapai ketahanan pangan, perbaikan nutrisi, serta mendorong budidaya pertanian yang berkelanjutan;

3. Kesehatan yang baik dan kesejahteraan (good health and well-being): menjamin kehidupan yang sehat serta mendorong kesejahteraan hidup untuk seluruh masyarakat di segala umur;

4. Pendidikan berkualitas (quality education): menjamin pemerataan pendidikan yang berkualitas serta meningkatkan kesempatan belajar untuk semua orang;

5. Kesetaraan gender (gender equality): mencapai kesetaraan gender dan memberdayakan kaum ibu dan perempuan;

6. Air bersih dan sanitasi (clean water and sanitation): menjamin ketersediaan air bersih dan sanitasi yang berkelanjutan untuk semua orang;

7. Energi bersih dan terjangkau (affordable and clean energy): menjamin akses terhadap sumber energi yang terjangkau, terpercaya, berkelanjutan dan modern untuk semua orang;

8. Pekerjaan yang layak dan pertumbuhan ekonomi (decent work and economic growth): mendukung perkembangan ekonomi yang berkelanjutan,

147 Jasser Auda, Membumikan Hukum Islam melalui Maqasid Syariah: Pendekatan Sistem, (Bandung: Mizan, 2015), hlm. 15.

148 www.globalgoals.org dan satu-indonesia.com, diakses pada 14 Juli 2018. 
lapangan kerja yang produktif serta pekerjaan yang layak untuk semua orang;

9. Industri, inovasi dan infrastruktur (industry, innovation and infrastructure): membangun infra stuktur yang berkualitas mendorong peningkatan industri yang berkelanjutan serta mendorong inovasi;

10. Mengurangi kesenjangan (reduced inequalities): mengurangi ketidaksetaraan baik di dalam sebuah negara maupun diantara negara negara di dunia;

11. Keberlanjutan kota dan komunitas (sustainable cities and communities): membangun kota-kota serta pemukiman yang berkualitas, aman dan berkelanjutan;

12. Konsumsi dan produksi yang bertanggungjawab (responsible consumption and production): menjamin keberlangsungan konsumsi dan pola produksi;

13. Aksi terhadap iklim (climate action): bertindak cepat untuk memerangi perubahan iklim dan dampaknya;

14. Kehidupan bawah laut (life below water): melestarikan dan menjaga keberlangsungan laut dan kehidupan sumber daya laut untuk perkembangan yang berkelanjutan;

15. Kehidupan di darat (life on land): melindungi, mengembalikan dan meningkatkan keberlangsungan pemakaian ekosistem darat, mengelola hutan secara berkelanjutan, mengurangi tanah tandus serta tukar guling tanah;

16. Institusi perdamaan dan peradilan yang kuat (peace and justice strong institutions). Meningkatkan perdamaian termasuk masyarakat untuk pembangunan berkelanjutan, menyediakan akses untuk keadilan bagi semua orang termasuk lembaga dan bertangungjawab untuk seluruh kalangan;

17. Kemitraan untuk mencapai tujuan (partnership for the goals): Memperkuat implementasi dan menghidupkan kembali kemitraan global untuk pembangunan yang berkelanjutan. Agar selaras dengan nilai-nilai Islam, maka The Global Goals terlebih dahulu harus ditelaah dari perspektif Islami, tepatnya maqashid syariah kontemporer.

\section{D.Telaah SDGs dari Perspektif Maqashid al-Syariah}

Perlindungan agama pada era globalisasi diarahkan pada terwujudnya perilaku religius yang mencerminkan kedamaian dan keadilan. Hal ini selaras dengan 17 Poin The Global Goals SDGs yang pada dasarnya juga mengusung 
perdamaian dan keadilan sehingga tercipta kesejahteraan umum. Hal ini selaras kandungan surat al-Nahl ayat 90 dan hadits riwayat Abu Mûsa al Asy'ari Ra: Para sahabat bertanya: “Wahai Rasulullah, Islam yang bagaimanakah yang lebih utama?". Rasulullah SAW bersabda: "Muslim yang membuat orang lain selamat dari (keburukan) lisan (perkataan) dan tangan (perbuatan)-nya."

Dari ayat dan hadis di atas, bisa disimpulkan bahwa seorang muslim hendaknya bisa berkontribusi positif kepada orang-orang yang ada disekitarnya dan lingkungannya. Baik melalui perkataan dan perbuatan, semisal membantu penyelenggaraan pendidikan Islam sesuai kompetensinya. Jika belum mampu, minimal perkataan dan perbuatannya tidak menimbulkan dampak negatif bagi orang lain. Misalnya tidak menyebarkan ajaran Islam garis keras yang dapat memicu tindak anarkis-teroris. Perlindungan jiwa raga diarahkan pada realisasi kesehatan yang baik dan kesejahteraan umum. Kesehatan yang baik terkait dengan kesehatan fisik, sedangkan kesejahteraan terkait dengan kesehatan psikis. Dalam Islam, kesehatan harus difungsikan semaksimal mungkin untuk aktivitas-aktivitas yang produktif dan bermanfaat, sebagaimana Hadits riwayat Ibnu Abbas RA: Rasulullah SAW bersabda: “Optimalkan lima hal sebelum (tiba) lima hal lainnya: Mudamu sebelum tuamu, sehatmu sebelum sakitmu, kayamu sebelum fakirmu, waktu luangmu sebelum waktu sibukmu, dan hidupmu sebelum wafatmu ${ }^{149}$.

Pendidikan berkualitas menjadi sasaran perlindungan akal dalam konteks masa kini. Wujudnya adalah reformasi pendidikan Islam secara total demi mewujudkan pendidikan yang berkualitas dari segi input, proses maupun output. Pendidikan Islam haruslah berorientasi pada pembinaan pribadi yang religius sebagaimana tersurat dalam surat Ali Imran ayat 190-191 dan surat alMujadilah ayat 11. Ayat tersebut memberikan landasan reformasi pendidikan Islam yang berorientasi pada pembinaan pribadi religious, penuh toleransi dan kompetitif.

\footnotetext{
149 HR. al-Hakim.
} 
Sedangkan perlindungan keluarga dewasa ini telah mengalami perkembangan cakupan. Hal ini harusnya bisa selaras dan bisa bersanding dengan kebutuhan dan tuntutan global. Sebagaimana telah dijelaskan Rosidin. Menurutnya:

"Perlindungan keluarga pada era globalisasi mengalami pemekaran, karena bukan hanya ditujukan pada perikemanusiaan, melainkan juga perikemakhlukan (meminjam istilah Harun Nasution). Poin global goals yang relevan dengan perikemanusiaan adalah keberlanjutan kota dan komunitas serta kemitraan untuk mencapai tujuan. Sedangkan poin global goals yang relevan dengan perikemakhlukan adalah air bersih dan sanitasi, aksi terhadap iklim, kehidupan bawah laut dan kehidupan di darat. Surat al Hujurat: 9-13 begitu jelas memaparkan pentingnya perikemanusiaan, sedangkan Surat al A'raf: 56 menegaskan pentingnya perikemakhlukan menurut ajaran Islam". ${ }^{150}$

Dua tahun belakangan, dunia mulai merasakan akan pentingnya poinpoin SDGs UNDP. Gejala kebutuhan global tersebut bisa dirasakan di beberapa di belahan dunia. contohnya kebutuhan akan ketersediaan air bersih, perbaikan sanitasi untuk mencegah banjir, aksi reboisasi, gerakan penanaman pohon dan penghijauan untuk menjaga iklim agar tidak mengalami global warming, melestarikan aneka hayati dan menjagaan terumbu karang di bawah laut. Menjaga daerah konservasi hewan langka yang dilindungi dan sebagainya. Semua itu harus dilakukan oleh semua pihak. Maka harus ada kerjasama antar berbagai elemen dalam mencapai tujuan yang telah disepakai bersama.

Kesejahteraan umum terumuskan dalam banyak poin dalam SDGs. Ada enam poin yang selaras dengan perlindungan harta, yaitu: tanpa kemiskinan; tanpa kelaparan; energi bersih dan terjangkau; pekerjaan yang layak dan pertumbuhan ekonomi; industri, inovasi dan infrastruktur; mengurangi kesenjangan; serta konsumsi dan produksi bertanggung jawab. Hal ini selaras dengan surat al-Baqarah ayat 267 dan al-Hasyr ayat 7 yang mendorong terciptanya kesejahteraan umum. Maka jika dirumuskan, 17 poin The Global Goals SDGs bisa diupayakan dalam realisasinya melalui penyelenggaraan pendidikan berbasis maqashid syariah. Berikut ini sebaran 17 poin The Global Goals dalam perspektif maqashid syariah:

\footnotetext{
150 Rosidin, Internasionalisasi Pendidikan Tinggi Islam Melalui Realisasi The Glogal Goals Berbasis Maqashid Syariah, dalam Jurnal Ulul Albab, Vol. 17, No. 1, 2016, hlm. 44.
} 


\begin{tabular}{l|l|l}
\hline 1 & $\begin{array}{l}\text { Hifzh al-Din } \\
\text { (Perlindungan Agama) }\end{array}$ & $\begin{array}{l}\text { (16) Institusi Peradilan yang Kuat dan } \\
\text { Kedamaian }\end{array}$ \\
\hline 2 & $\begin{array}{l}\text { Hifzh al-Nafs } \\
\text { (Perlindungan Jiwa- } \\
\text { Raga) }\end{array}$ & $\begin{array}{l}\text { (3) Kesehatan yang Baik dan Kesejahteraan } \\
\text { (11) Keberlanjutan Kota dan Komunitas }\end{array}$ \\
\cline { 2 - 3 } $\begin{array}{l}\text { Hifzh al-'Irdl } \\
\text { (Perlindungan Harga } \\
\text { Diri) }\end{array}$ & $\begin{array}{l}\text { (5) Kesetaraan Gender } \\
\text { Hifzh al-'Agl } \\
\text { (Perlindungan Akal) }\end{array}$ & $\begin{array}{l}\text { (4) Pendidikan Berkualitas } \\
\text { Hifzh al-Nasl } \\
\text { (Perlindungan } \\
\text { Keluarga) }\end{array}$ \\
\hline 5 & $\begin{array}{l}\text { (17) Kemitraan untuk Mencapai Tujuan; } \\
\text { (6) Air Bersih dan Sanitasi } \\
\text { (13) Aksi terhadap Iklim } \\
\text { (14) Kehidupan Bawah Laut } \\
\text { (15) Kehidupan di Darat }\end{array}$ \\
\hline Perlindungan Harta) & $\begin{array}{l}\text { (1) Tanpa Kemiskinan } \\
\text { (2) Tanpa Kelaparan } \\
\text { (7) Energi Bersih dan Terjangkau } \\
\text { (8) Pekerjaan yang Layak dan Pertumbuhan } \\
\text { Ekonomi } \\
\text { (9) Industri, Inovasi dan Infrastruktur } \\
\text { (10) Mengurangi Kesenjangan } \\
\text { 12) Konsumsi dan Produksi Bertanggung } \\
\text { Jawab }\end{array}$ \\
\hline
\end{tabular}

\section{E. Pendidikan Berbasis Maqashid Syari'ah}

Konsep maqashid syari'ah kontemporer mengalami pergeseran, dari "penjagaan" dan "perlindungan" menuju "pengembangan" dan "hak-hak asasi". Pergeseran ini merupakan kontribusi Ibnu 'Asyûr yang membuka pintu bagi para cendekiawan kontemporer untuk mengembangkan teori maqashid dalam berbagai cara baru. Orientasi pandangan yang baru itu bukanlah konsep perlindungan (Hifzh) versi al-Ghazali, melainkan konsep "nilai" dan "sistem" versi Ibnu 'Asyûr. Berikut ini penjelasan lebih detailnya ${ }^{151}$

\section{Hifzh al-Din (Perlindungan Agama)}

Konsep pendidikan yang bisa diterapkan dalam kerangka hifzh al-din dengan tujuan untuk merealisasikan butir ke-16 The Global Goal SDGs, dapat diterapkan dalam dua skema. Pertama, kaitannya dengan realisasi institusi 
peradilan yang kuat, dengan cara menghadirkan pendidikan yang membentuk karakter yang religius dan menanamkan semangat ruh al-da'wah terhadap masyarakat sekitar. Sehingga setiap individu terdorong untuk sadar hukum dan dapat menegakkan hukum yang adil. Pendidikan karakter religius juga meliputi di dalamnya pendidikan anti korupsi dan anti rasuah.

Perlindungan agama dalam pendidikan juga bisa diterapkan dengan penyelenggaraan pendidikan karakter. KH. Hasyim Asy'ari menilai bahwa menuntut ilmu merupakan ibadah untuk mencari ridha Allah, yang mengantarkan manusia untuk memperoleh kebahagiaan dunia dan akhirat. Niat beribadah dalam menuntut ilmu merupakan akhlak yang dikatagorikan Asy'ari sebagai kode etik yang harus dimiliki oleh para penuntut ilmu. Menjadikan ibadah sebagai motivasi dalam pendidikan merupakan satu dari sepuluh kode etik seorang murid.

"Hendaknya (seorang murid) memiliki niat yang baik dalam mencari ilmu, yaitu dengan bermaksud mendapatkan ridha Allah, mengamalkan ilmu, menghidupkan syariat Islam, menerangi hati dan mengindahkannya, dan mendekatkan diri kepada Allah. Jangan sampai berniat hanya ingin mendapatkan kepentingan duniawi seperti mendapatkan kepemimpinan, pangkat, dan harta; atau menyombongkan diri di hadapan orang; atau agar orang lain hormat kepadanya."152

Dari penjelasan di atas, dapat ditarik sebuah kesimpulan bahwa Penyelenggaraan pendidikan memiliki dua dimensi. Pertama, pendidikan dimaksudkan untuk mendapatkan ridha Allah, dimensi ini masuk dalam tujuan pendidikan pada dimensi seorang mukallaf atau murid. Sedangkan dimensi yang kedua adalah menghidupkan syariat Allah, dimensi ini masuk dalam tujuan pendidikan pada dimensi syari' atau Allah. Sebagaimana teori yang ditawarkan oleh al-Syatibi dalam muwaqatnya, bahwa tujuan penetapan hukum dalam Islam terbagi menjadi dua sisi, untuk kepentingan Tuhan, dan di lain sisi untuk kepentingan pemeluknya. Ia mengatakan:

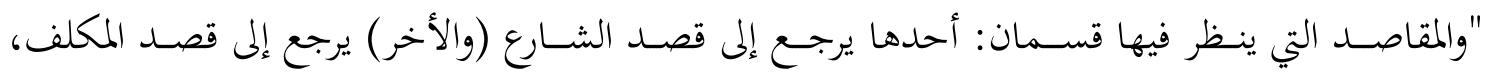

152 Hasyim Asy'ari, Pendidikan Akhlak untuk Pengajar dan Pelajar, Terjemah Kitab Adabul 'Alim wal Muta'allim, (Jombang: Pustaka Tebuireng, 2016), hlm. 19. 


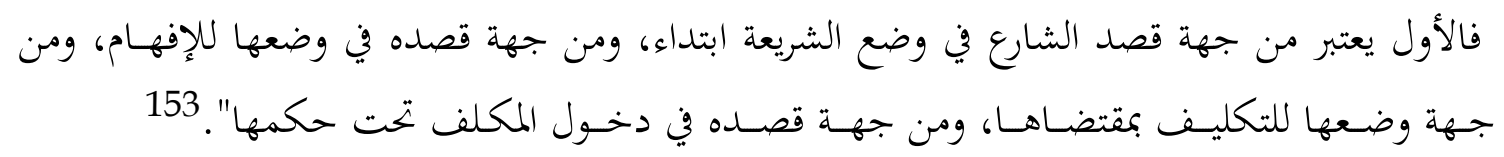

Dari ungkapan di atas, al-Syatibi membuka pikiran ulama pada zamannya, bahwa ayat al-Qur'an sebagai objek primer dalam kajian Islam harusnya juga dilihat dari perspektif pemeluknya/mukallaf (Antropocentris). Hal ini diperlukan agar Islam sebagai agama tidak dipandang hanya dari sisi wahyu belaka (Teocentris), tetapi juga dari sisi pemeluknya (Antropocentris) ${ }^{154}$.

Adapun pelaksanaan pendidikan dalam kaitannya dengan Hifzh al-din dalam tujuan menciptakan istitusi peradilan yang kuat terdapat dua dimensi tujuan. Pertama agar seorang murid dengan ilmunya bisa mendekatkan diri kepada Allah Swt, sehingga ia mendapatkan ridha-Nya. Selanjutnya dengan kedekatan dengan Allah Swt mendorongnya untuk bersikap religius, bertaqwa, anti korupsi dan anti rasuah. Kedua dari segi sosial, seorang murid dapat mengamalkan ilmunya, sehingga ia bisa menghidupkan syariat Islam dan melestarikan nilai-nilai Islam. hal ini dapat dilaksanakan melalui pembentukan ruh al-da'wah di dalam diri murid. Sehingga ia bisa berinteraksi dengan lingkungan sekitarnya dan berdakwah menanamkan nilai-nilai Islam, sehingga syariat Islam akan hidup di tengah-tengah masyarakat.

Dari paparan di atas, dapat disimpulkan bahwa tujuan pendidikan bukan hanya untuk sekedar menghilangkan kebodohan. Sedangkan pengamalan ilmu pengetahuan dalam proses pendidikan adalah menghidupkan syari'at Islam. Dalam konsep pendidikannya, Asy'ari lebih

\footnotetext{
${ }^{153}$ Abû Ishâq al-Syâthibi, al-Muwâfaqat...., Vol. II, hlm. 5.

${ }^{154}$ Maqasid syari'ah berarti tujuan Allah dan Rasul-Nya dalam merumuskan hukum-hukum Islam. Tujuan itu dapat ditelusuri dalam ayat-ayat Al-Qur'an dan Sunnah Rasulullah sebagai alasan logis bagi rumusan suatu hukum yang berorientasi kepada kemaslahatan umat manusia. Sebagaimana dikemukakan oleh Abu Ishaq al-Syatibi bahwa tujuan pokok disyariatkan hukum Islam adalah untuk kemaslahatan manusia baik di dunia maupun di akherat. Lebih lanjut Abu Ishaq al-Syatibi melaporkan hasil penelitian para ulama terhadap ayat-ayat Al-Qur'an dan Sunnah Rasulullah bahwa hukum-hukum disyariatkan Allah untuk mewujudkan kemaslahatan umat manusia, baik di dunia maupun akhirat kelak. Kemaslahatan yang akan diwujudkan itu menurut al-Syatibi terbagi kepada tiga tingkatan, yaitu kebutuhan dharuriyat, kebutuhan hajiyat, dan kebutuhan tahsiniyat. Lihat: Abû Ishâq al-Syâthibi, al-Muwâafaqat..., Vol II, hlm. 6.
} 
fokus kepada persoalan-persoalan etika dalam mencari dan menyebarkan ilmu. Beliau berpendapat bahwa bagi seorang yang akan mencari ilmu pengetahuan (muta'allim) atau menyebarkan ilmu pengetahuan (mu'allim), yang pertama harus ada pada diri mereka adalah niatan semata-mata untuk mencari ridho Allah Swt.

Point tujuan kedua, yang berkaitan dengan kedamaian dalam kaitannya dengan hifzh al-din adalah dengan mengusung konsep pendidikan toleransi terhadap hak beragama. Dahulu pemaknaan yang muncul atas hifzh al-din dalam literatur fiqh konservatif bermakna hukuman atas meninggalkan keyakinan yang benar (versi al-Amiri). Namun, akhir-akhir ini pemaknaan tersebut bergeser menjadi "kebebasan kepercayaan" (freedom of faiths) versi Ibnu 'Asyûr atau "kebebasan berkeyakinan" dalam ungkapan kontemporer lain. Upaya mengubah paradigma Hifzh al-Din ini dilakukan misalnya oleh Ibnu 'Asyûr. 155 Ia menggeser Hifzh al-Din dari paradigma sanksi bagi orang murtad menuju paradigma kebebasan beragama (مَنْ بَدَّلَ دِيْنَهُ فَاَقتُلْوُهُ)

Selain pemaknaan di atas, Muhammad al-Shāwi menjelaskan cakupan Hifzh al-Din juga bisa berupa jaminan dalam mempertahankan kebenaran dalam keyakinan, dan menjadi hak seseorang dalam menjalankan praktek ibadah yang ia yakini. Termasuk di dalamnya juga pemeliharaan agama dari prasangka subyektif, seperti penghinaan dan ujaran kebencian, dan mengatas namakan Tuhan secara salah, dengan tujuan menghancurkan agama, dan menyebar provokasi. ${ }^{156}$ Maka dalam dunia pendidikan, pemeliharaan agama bisa dilakukan dengan menanamkan aqidah yang kuat sejak dini. Para pelajar muslim harus ditanamkan bahwa Islam satu-satunya agama yang diterima dan diridhoi Allah Swt dan agama yang sempurna, sebagaimana firman-Nya dalam surat Ali ‘Imran ayat 19, Ali ‘Imran ayat 85 dan al-Maidah ayat 3.

155 Rosidin, "Problematika Pendidikan Islam Perspektif Maqasid Shari'ah", dalam Jurnal Ma'arij; Jurnal Studi Keislaman, Vol. 03, No. 01, September 2016, hlm. 190.

156 Muhammad al-Shāwi, "Al-Maqāshid al-Ulyā li al-Tarbiyah," dalam Jurnal Ma'rifah, Kementerian Pendidikan Saudi Arabiyah, edisi bulan Juli (2009), hlm. 6. 


\section{Hifzh al-Nafs (Perlindungan Jiwa Raga)}

Islam sangat menghargai jiwa manusia. Allah SWT melarang hambaNya untuk menyakiti sesama, apalagi sampai membunuhnya. Bahkan Allah SWT memberi ancaman keras kepada pelakunya sebagaimana firman Allah Swt dalam surat al-Isra' dan al-Nisa' ayat 93. Al-Shāwi juga mengartikan Hifzh al-Nafs dengan makna perlindungan hak asasi manusia dalam kehidupannya, dan perlindungan terhadap semua bentuk intimidasi. Bahkan larangan menyakiti terhadap hewan tanpa diiringi kemaslahatan di dalamnya. Begitu juga larangan intimidasi terhadap individu atau pun bangsa, apakah itu berbetuk serangan atau penyiksaan, atau tindakan yang menyebabkan kerusakan dengan menggunakan senjata pemusnah, zat karsinogen atau obatobatan eksperimental. ${ }^{157} \mathrm{Hal}$ ini sangat relevan dengan the global goal tentang kesehatan dan keberlanjutan kota dan komunitas.

Oleh karena itu, pendidikan dalam pandangan Islam harus menanamkan rasa kasih sayang terhadap sesama, bahkan terhadap makluk lain. Berbagai perilaku yang mengancam dan berpotensi menghilangkan jiwa seseorang harus dihentikan. Para pendidik harus menutup jalan terjadinya bullying, perpeloncoan dengan dasar bahwa ajaran Islam sangat menjaga kehormatan dan harga diri pemeluknya (Hifzh al-'Irdl). Lebih dari itu, maka perilaku kriminal murid kepada guru yang mengancam keselamatan jiwa sangatlah tidak dibenarkan dalam Islam. Jika hal ini menjadi perhatian, maka tidak akan terjadi lagi perkelahian antar pelajar, tidak ada lagi intimidasi dan korban nyawa di kalangan akademisi. Yusuf al-Qardhāwi menggolongkan Hifzh al-Irdh (perlindungan kehormatan) masuk dalam bagian Hifzh al-Nafs. Semula berkisar pada penjagaan jiwa raga dan harga diri, namun akhir-akhir ini berangsur-angsur diganti oleh "perlindungan harkat dan martabat manusia", bahkan "perlindungan hak-hak asasi manusia". ${ }^{158}$ Dalam konteks Global, Hifzh al-Irdh juga mencakup tentang isu kesetaraan gender. Artinya jika

\footnotetext{
157 al-Shāwi, Al-Maqāshid ..., hlm. 7.

158 Rosidin, Internasionalisasi ..., hlm. 48.
} 
laki-laki atau perempuan menanggung peran dan tanggung jawab yang sama, maka mereka berhak memperoleh hak yang sama. Dan jika keduanya memainkan peran yang berbeda, maka haknya pun tentu tidak sama. Namun di dalam segala bidang profesi dan karir, baik laki-laki dan perempuan berhak untuk memperoleh kesempatan yang sama.

\section{Hifzh al-Aql (Perlindungan Akal)}

Jika selama ini pemaknaan Hifzh al-'Aql masih terbatas pada larangan minum-minuman keras, maka sekarang telah berkembang menjadi 'pengembangan pikiran ilmiah', 'perjalanan menuntut ilmu', 'melawan mentalitas taklid', dan 'mencegah mengalirnya tenaga ahli keluar negeri';159 Dengan kata lain, Hifzh al-'Aql bisa dimaknai dengan penyelenggaraan pendidikan yang berkualitas, yang mendorong murid untuk selalu berinovasi dan mengembangkan bakat. Perhatian Islam terhadap akal bisa dilihat dengan banyaknya ayat yang berbicara tentang akal. Imam Syafi'i menjadikan akal yang cerdas sebagai syarat utama meraih ilmu $\left(d z a k a^{\prime}\right)$ sebelum syarat lainnya.

Al-Shāwi menambahkan bentuk menjaga akal bisa juga berupa hak untuk belajar, hak untuk mendapatkan informasi, dan hak mendapatkan proteksi terhadap hal yang bisa membahayakan akal pikiran seperti narkoba, ajaran sesat dan informasi yang salah. Termasuk di dalamnya juga hak untuk mengembangkan pikirannya yang mengarahkannya kepada sifat humanis dalam segala aspek, sehingga ia bisa menciptakan sebuah penemuan yang bermanfaat untuk kemanusiaan. ${ }^{160}$ Lebih jauh, Abd al-Shamad al-Hanawi memaknai Hifzh al-Aql sebagai hak kebebasan berpikir "al-Hurriyyah alFikriyyah". Dalam artian seseorang memiliki kebebasan berpikir intelektual yang disertai kepercayaan individunya, sehingga dia tidak jatuh di depan yang lain karena kelebihan yang dimiliki orang lain. Kepercayaan diri dan pemikiran intelektualnya bisa membuat sebuah diskusi menjadi hidup dan sumber pertukaran gagasan dan pemikiran sehingga tercipta atmosfir akademis dan

\footnotetext{
159 Ibid, hlm. 45.

160 Muhammad al-Shāwi, Al-Maqashid..., hlm. 8.
} 
jauh dari kejumudan pemikiran. ${ }^{161}$. Selain itu, bentuk Hifzh al-Aql adalah larangan untuk bertaqlid buta. seseorang harus membebaskan pikiran mereka untuk berinovasi dan melakukan penelitian. Sehingga ia bisa terlepas dari subordinasi bawahan pendahulunya sehingga ia dapat mengetahui suatu kebenaran dari dirinya, mengetahui duduk permasalahan serta landasan hukum yang menyertainya. Sebagaimana disinggung dalam surat Al-Zuhruf ayat $23-24$.

\section{Hifzhh al-Nasl (Perlindungan Keturunan)}

Pada abad ke-20 M para penulis maqashid secara signifikan mengembangkan 'perlindungan keturunan (keluarga)' menjadi teori berorientasi keluarga, misalnya 'peduli keluarga. ${ }^{162}$ Al-Shāwi menambahkan konsep Hifzh al-Nasl juga dapat diimplementasikan dalam bentuk menyiapkan generasi yang paling lebih baik, sehat dari penyakit fisik dan psikologis. Dengan jalan menjaga generasi penerus dari hal-hal yang dapat melemahkan atau menghambat jalur alaminya dan perkembangannya dengan baik. Mereka juga mempunyai hak atas lingkungan yang sesuai dan mendukung daya kembangnya. 163 Pemikiran Al-Shāwi tentang konsep Hifzh al-Nasl dalam konteks jaminan lingkungan sehat yang mendukung tumbuh kembang pelajar di atas mempunyai relevansi dengan empat point the global goal (6) Air Bersih dan Sanitasi; (13) Aksi terhadap Iklim; (14) Kehidupan Bawah Laut; (15) Kehidupan di Darat. Gejala di atas agaknya telah dipikirkan oleh Kementerian Pendidikan dan Kebudayaan. Baru-baru ini, Kemendikbud meluncurkan Program Penguatan Pendidikan Karakter (PPK) ${ }^{\mathbf{1 6 4}}$ sebagai tanggapan solutif

161 Abd al-Shamad al-Hanawi, al-Maqashid al-Tarbawiyyah li al-Hiwar fi al-Qur'an al-Karim, (2017), hlm. 5.

162 Rosidin, Internasionalisasi..., hlm. 48.

163 Muhammad al-Shāwi, Al-Maqashid ..., hlm. 7.

164 Di tahun 2016 sebanyak 542 sekolah (SD dan SMP) telah tergabung menjadi sekolah percontohan penerapan program Penguatan Pendidikan Karakter. Sekolah-sekolah tersebut merupakan sekolah yang telah menerapkan berbagai praktik baik pendidikan karakter sehingga diharapkan mampu menjadi contoh/teladan dan menularkan "virus kebaikan" dalam penerapan PPK di sekitarnya. Sekolah-sekolah yang dipilih juga ditentukan berdasarkan keterwakilan provinsi, kondisi geografis, maupun status sekolah negeri dan swasta. Implementasi program Penguatan Pendidikan Karakter akan dilaksanakan secara bertahap. Di 
atas problem kemerosotan karakter bangsa Indonesia. Program PPK ini juga mendisain terwujudnya lingkungan sehat yang bisa mendukung daya kembang dan potensi anak didik. Pihak sekolah, keluarga dan lingkungan mempunyai peranannya masing-masing dalam mensukseskan program ini. Guru dapat mengintegrasikan nilai-nilai karakter dalam pembelajaran di kelas dan mampu mengelola manajemen kelas. Kepala Sekolah dapat mendesain budaya sekolah yang menjadi ciri khas dan keunggulan sekolah tersebut. Lalu, Sekolah mampu mendesain pelibatan publik guna meningkatkan peran orang tua dan masyarakat. Sehingga target capaian menuju Generasi Emas 2045 yang telah ditetapkan Kemendikbud bisa terealisasi.

Oleh karenanya, menciptakan lingkungan keluarga yang sehat dan baik menjadi penting. Linkungan yang kondusif dapat membentuk kepribadian dan dapat mempengaruhi perkembangan anak. Sebagaimana teori Latensi milik Talcott Parsons yang menyimpulkan bahwasanya setiap masyarakat akan terbentuk sebuah pola hubungan yang saling terkait. Setiap anggota masyarakat harus mempertahankan, memperbaiki, baik motivasi individu maupun pola budaya yang menciptakan dan mempertahankan motivasinya. Latensi menunjuk pada kebutuhan mempertahankan nilai-nilai dasar serta norma budaya yang dianut bersama oleh para anggota dalam masyarakat. 165

\section{Hifzh al-Mal (Perlindungan Harta)}

Jika semula Hifzh al-Mal bermakna 'hukuman bagi pencurian' versi alAmidi dan 'proteksi uang' versi al Juwaini, akhir-akhir ini berkembang menjadi istilah-istilah sosio-ekonomi yang familier, misalnya 'bantuan sosial', 'pengembangan ekonomi', 'distribusi uang', 'masyarakat sejahtera' dan

tahun 2017, Kemendikbud menargetkan sebanyak 1.626 sekolah akan menjadi target rintisan PPK, yang akan memberikan dampak pada sekitar 9.830 sekolah di sekitarnya. Hingga tahun 2020, target implementasi penuh PPK diharapkan dapat terwujud. Tentu, implementasi PPK menyesuaikan dengan kapasitas dan kemampuan sekolah. Diharapkan, keberhasilan satuan pendidikan yang menjalankan PPK dapat menjadi teladan/inspirasi bagi seluruh satuan pendidikan lainnya. Lihat: http://cerdasberkarakter.kemdikbud.go.id/, diakses pada 15 Juli 2018.

165 George Ritzer, Sosiologi Ilmu Pengetahuan Berparadigma Ganda, (Jakarta: PT Rajagrafindo Persada, 2014), hlm. 102-105. 
'pengurangan perbedaan antar-kelas sosial-ekonomi'. Pengembangan ini memungkinkan penggunaan maqashid untuk mendorong pengembangan ekonomi, yang sangat dibutuhkan di kebanyakan negara-negara berpenduduk mayoritas muslim. ${ }^{166}$ Maka pendidikan yang berbasis maqashid syari'ah harus bisa menciptakan kesejahteraan umum dalam aspek sosio-ekonomi.

Peran pendidikan sebenarnya sangat penting dalam pengentasan kemiskinan. Konsep pendidikan untuk pengentasan kemiskinan mempunyai dua makna. Makna pertama didasarkan pada teori human capital yang menyatakan bahwa di samping modal dan teknologi, manusia juga merupakan salah satu faktor utama untuk mendukung pertumbuhan ekonomi suatu negara. Pertumbuhan ekonomi di Jepang, Korea Selatan dan Singapura contohnya. Kedua negara ini miskin sumber daya alam, tetapi pertumbuhan ekonominya tinggi karena mempunyai sumber daya manusia dengan kompetensi tinggi, terutama di bidang teknologi dan ilmu pengetahuan.

Makna kedua berkaitan dengan kebijakan afirmatif. Kebijakan ini pada prinsipnya menegaskan bahwa pelayanan pendidikan harus bersifat non diskriminatif. Minat dan bakat menjadi satu-satunya dasar untuk melakukan seleksi (bukan mendiskriminasikan) setiap siswa untuk mendapatkan pelayanan pendidikan. Kebijakan pendidikan, baik di negara berkembang maupun maju, selalu diarahkan pada peningkatan pemerataan dan mutu pelayanan pendidikan. Sehingga peran pendidikan dalam kaitannya dengan Hifzh al-Mal dapat menjadi jembatan untuk merealisasikan tujuh point the global goal antara lain: (1) Tanpa Kemiskinan; (2) Tanpa Kelaparan;(7) Energi Bersih dan Terjangkau; (8) Pekerjaan yang Layak dan Pertumbuhan Ekonomi; (9) Industri, Inovasi dan Infrastruktur; (10) Mengurangi Kesenjangan; (12) Konsumsi dan Produksi Bertanggung Jawab.

Dari paparan argumen dan penjelasan tentang pendidikan yang berbasis pada lima maqashid syari'ah, bisa disimpulkan ilustrasi grafis dari formulasi The

\footnotetext{
166 Rosidin, Internasionalisasi..., hlm. 49.
} 
Global Goal SDGs dari perspektif maqashid syari'ah sebagai pendekatan terhadap pendidikan Islam sebagaimana berikut:

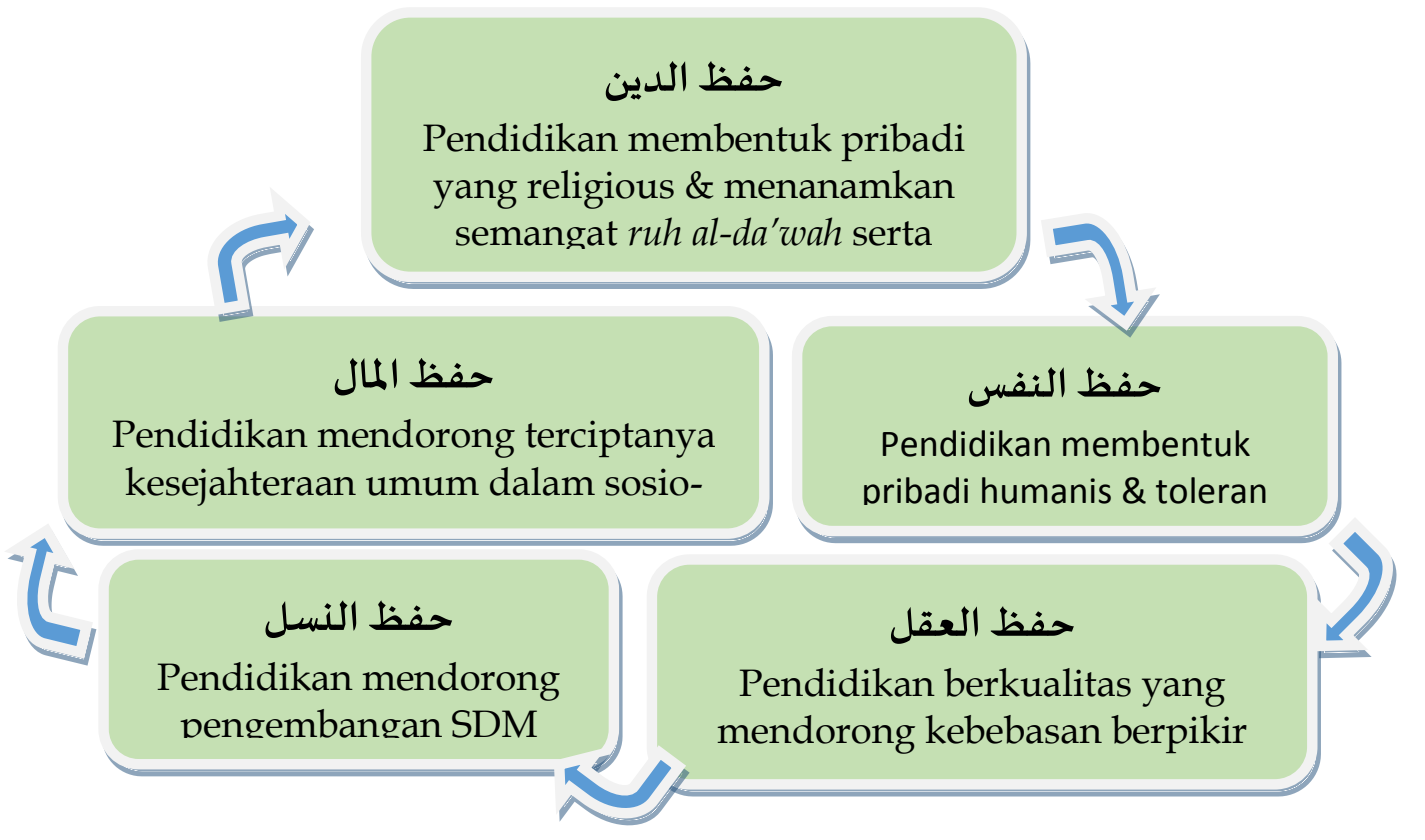

\section{F. Kesimpulan}

Meski kajian maqashid syari'ah menjadi domain disiplin ilmu syari'ah, namun Abdurrahman al-Nahlawi menilai konsep mashlahah ini memiliki hubungan yang erat dengan pendidikan. Oleh karena itu, konsep mashlahah harus menjadi tujuan yang harus dicapai dan diwujudkan. Ilmu pengetahuan dalam ranah pengamalannya diharapkan bisa menciptakan kemaslahatan untuk semua pihak. Baik dalam skala kecil maupun skala yang lebih besar. Dalam skala besarnya, ada 17 Mashlahah yang bersifat global yang ditetapkan oleh PBB dan telah disepakati oleh 193 negara anggota PBB yang berkomitmen untuk mewujudkannya. Mashlahah dalam bentuk Sustainable Development Goals (Tujuan Pembangunan Berkelanjutan) yang disingkat dengan "SDGs" menjadi fokus perhatian mayoritas negara di dunia ini telah dimulai hingga Desember 2030.

Pendidikan sebagai instrumen pembangunan Sumber Daya Manusia (SDM) yang mendorong untuk cakap dalam mengelola dan memanfaatkan Sumber Daya Alam (SDA) harusnya bisa memainkan peranan penting dalam 
upaya realisasi program Sustainable Development Goals (SDGs). Tujuan pendidikan yang berorientasi pada program SDGs bisa dikonsepsi dengan pendekatan maqashid syari'ah. Karena Ibn 'Asyûr beranggapan kemaslahatan yang akan diraih dengan memelihara maqashid syari'ah merupakan tujuan utama syariah Islam. Dalam rangka mewujudkan keteraturan alam dan memelihara kehidupan dari kerusakan, dan itu artinya syariah Islam diturunkan untuk mewujudkan mashlahah dan menjauhkan mafsadah. Baik mashlahah tersebut berdampak secara individu maupun kolektif. Dunia secara umum telah menyepakati program SDGs sebagai mashlahah kolektif yang dicapai secara berkesinambungan. 193 negara anggota PBB telah berkomitmen untuk mewujudkan cita-cita bersama yang tertuang dalam 17 poin mashlahah SDGs. Dari sini, telah jelas akan adanya relevansi antara tringual pendidikan, maqashid syari'ah dan SDGs.

\section{DAFTAR PUSTAKA}

Asy'ari, Hasyim, Pendidikan Akhlak untuk Pengajar dan Pelajar, Terjemah Kitab Adabul 'Alim wal Muta'allim, Terj. Tim Dosen Ma'had Aly. Jombang: Pustaka Tebuireng, 2016.

Auda, Jasser, Membumikan Hukum Islam Melalui Maqashid Syariah: Pendekatan Sistem, 2015.

Ghazalī ,Muhammad Abu Hamīd, al-Musthasfâ min 'Ilm al-Ushûl, Kairo: Dar alHadits, 2011.

Hakim, Muhammad Lutfi, “Pergeseran Paradigma Maqāsid Al-Syari'ah: Dari Klasik Sampai Kontemporer," dalam Jurnal Al-Manahij, Vol. X, No. 1, 2016. Hanawi, Abd al-Shamad, al-Maqashid al-Tarbawiyyah li al-Hiwar fi al-Qur'an alKarim, t.kt: t.p. 2017.

Ibn 'Asyûr, Țahir, Maqāsid al-Syarī'ah al-islamiyah, Amman: Dar al-Nafais, Bandung: Mizan, 2001.

Izz al-Din bin Zaghifah, al-Maqashid al-'Âmmah li al-Syari'at al-Islamiyah (Kairo: Dar al-Shafwah li al-Thaba'ah wa al-Nasyr wa al-Tawzi', 1996. 
Mawardi, Kholid, Moralitas Pemikiran Pendidikan KH. Hasyim Asy'ari, Yogyakarta: Insania, Jurnal Pemikiran Alternatif Pendidikan, 2008.

Muammar, M. Arfan, Studi Islam: Perspektif Insider/Outsider, Jogjakarta: IRCiSoD, 2013.

Nahlawi, Abdurrahman, Pendidikan Islam di Rumah, Sekolah dan Masyarakat, Jakarta: Gema Insani Press, 1995. , Ushûl al-Tarbiyah al-Islâmiyah, Beirut: Dar al-Fikr, 2003.

Ramadan, Tariq, Radical Reform: Islamic Ethics and Liberation, Oxford: Oxford University Press, 2008.

Ritzer, George, Sosiologi Ilmu Pengetahuan Berparadigma Ganda, Jakarta: PT Raja grafindo Persada, 2014.

Rosidin, “Internasionalisasi Pendidikan Tinggi Islam Melalui Realisasi The Glogal Goals Berbasis Maqashid Syariah," dalam Jurnal Ulul Albab, Vol. 17, No. 1, 2016.

, "Problematika Pendidikan Islam Perspektif Maqasid Shari'ah", dalam Jurnal Ma'arij; Jurnal Studi Keislaman, Vol. 03, No. 01, September 2016.

Shāwi, Muhammad, "Al-Maqashid al-Ulya li al-Tarbiyah," dalam Jurnal Ma'rifah, Kementerian Pendidikan Saudi Arabiyah, edisi bulan Juli, 2009.

Syāthibi, Abu Ishaq, -Muwâfaqat, Kairo: Dar al-Fadhilah, 2010.

Zabidi, Ahmad Zayyaduz, "Paradigma Utilitarianistik dalam Istimbat Hukum Islam", dalam Jurnal al-Ihkam, Vol. 07, No. 2, Desember 2012. (10.19105/alihkam.v7i2.335)

Zayd, Mushthafa, al-Mashlahah fî Tasyri' al-Islami, Beirut: Maktabah Wahdah, t.t. 